\title{
"AN ANALYSIS OF THE BANK SPECIFIC FACTORS AFFECTING THE NON PERFORMING LOANS IN COMMERCIAL BANKS IN SRI LANKA"
}

\author{
BY \\ Sathasivam Karthikasan \\ (5266FM20 13034)
}

A Research submitted to the University of Sri Jayewardenepura in partial fulfillment of the requirements for the Degree of Master of Business Administration on 2016 


\section{Declaration by the candidate}

The work described in this Research was carried out by me under the supervision of Dr.P.J.Kumarasinghe and a report on this has not been submitted $\mathrm{n}$ whole or in part to any university or any other institution for another Degree.

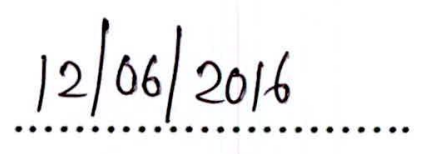

Date 


\section{Declaration of the Supervisor}

certify that the above statement made by the candidate is true that the Research is suitable for submission to the University for the purpose of valuation.

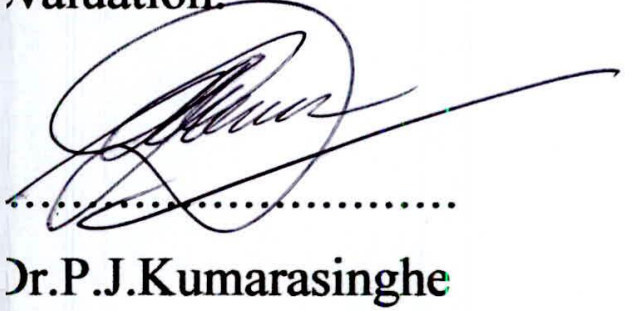

$14 \cdot 06 \cdot 2016$

Date 


\section{Acknowledgment}

I have intended the title "An analysis of the bank specific factors affecting to the non performing loans commercial bank, Sri Lanka. As a research study and I submitted to the Faculty of Graduate Studies, University of Sri Jayewardenepura, Sri Lanka in partial fulfillment for the Master of Business Administration (MBA) Degree.

First I thank the god for his gracious help and bless in completing my research work satisfactorily. I wish to convey my sincere thanks and heartfelt gratitude in the first instance to supervisor and coordinator of MBA/MPM/M.Sc. Programme, Dr.P.J.Kumarasinghe Senior Lecturer, University of Sri Jayewardenepura for his generous and untiring efforts extended to me in all phase of the preparation of this research study. He spent several patient and valuable time, with his unhesitant help and valuable suggestions, which no doubt resulted in my successful completion of this book.

I thank Senior Professor (Mrs.) Swarna Piyasiri, Dean, Faculty of Graduate Studies, University of Sri Jayewardenepura. This needs delicate handling and a sense of righteousness.

I express my gratitude to the employees of Commercial bank who have answered the questionnaires properly. I wish to thank the staff of Library, computer unit who helps me to prepare this study.

More ever, I gratitude to my family and friends immensely given support, and me the necessary moral strength that made by research study quite pleasant. I also wish to thank each and every one who has helped in numerous ways to carry on my research smoothly and make the study a great success. 


\begin{abstract}
Banks role in the economy of any country is very significant. They play intermediation function in that they collect money from those who have excess and lend it to others who need it for their investment. Availing credit to borrowers is one means by which banks contribute to the growth of economics. The principal profitmaking activity of commercial banks is making loans to its customers. In allocating funds, the primary objective of bank management is to earn income while serving the credit needs of its community.
\end{abstract}

NPLs create problems for the banking sector's balance sheet on the asset side. They also create a negative impact on the income statement as a result of provisioning for loan losses. In the worst scenario, a high level of NPLs in a banking system poses a systemic risk. The main objective of the research was to find out the bank specific factors affecting of Nonperforming loan in Commercial bank, Sri Lanka.

The target population comprised a total of 25 Licensed Commercial banks out of which a sample of 10 and 100 employees was using stratified simple random sampling. The data was collected by use of self developed questionnaire issued to the Credit manager, Loan officers and executives. The data was analyzed by using statistical software (SPSS 16) and tabulated by use of tables and figures. The findings revealed, some bank specific factors maximize reflect in case of nonperforming loans. 


\section{TABLE OF CONTENTS}

CONTENTS

PAGE NO

Acknowledgement

Abstract

II

Table of contents

III

List of table VII

List of figure $\mathrm{X}$

Appendix -1 $\mathrm{X} 1$

References

XII

\section{CHAPTER-01 INTRODUCTION}

01- 03

1.1 Background of Study

1.2 Problem Statement 01

1.3 Research Objectives

1.4 Research Questions

1.5 Significance of the study

1.6 Scope of the study

1.7 Limitation of the research

1.8 Summary

2.1 Introduction

2.2 Bank Lending

2.3 The Five C's of Credit 
2.3.2 Capacity 05

$\begin{array}{ll}2.3 .3 \text { Capital } & 05\end{array}$

$\begin{array}{ll}\text { 2.3.4 Conditions } & 05\end{array}$

$\begin{array}{ll}\text { 2.3.5 Collateral } & 06\end{array}$

2.4 Nonperforming Loans (NPL) 06

$\begin{array}{ll}2.5 \text { Causes of Non-Performing Loans } & 07\end{array}$

2.5.1 Reduced attention to borrowers 07

2.5.2 Macroeconomic Instability 08

2.5.3 Lack of Strict Admittance policies and no active exit 08

2.5.4 Increasing loan size increases risk $\quad 09$

2.5.5 Lenders lack plans to deal with risk 09

2.5.6 Borrowers probe a credit operation's weaknesses 10

$\begin{array}{ll}2.5 .7 \text { Rent seekers capture the credit programme } & 10\end{array}$

2.5.8 Lenders and project designers have low expectation 10

2.5.9 The lender is unwilling to collect $\quad 10$

2.5.10 Lack of good models $\quad 11$

2.5.11 Loan sanctioned by corruption $\quad 11$

2.5.12 Donors gives loans to dominate 11

2.5.13 Weak follow up weaken the system 11

2.6 Issues Faced in NPL Management 12

$\begin{array}{ll}2.7 \text { Empirical Review } & 13\end{array}$

2.7.1 Macroeconomic factors and Non performing loans 13

$\begin{array}{ll}\text { 2.7.2 Bank specific factors and Non performing loans } & 17\end{array}$

$\begin{array}{ll}\text { 2.7.2.1 Rapid credit growth and NPLs } & 21\end{array}$

$\begin{array}{ll}\text { 2.7.2.2 Monitoring NPLs } & 21\end{array}$

2.7.2.3 Interest and NPLs $\quad 22$

2.7.2.4 Risk Assessment and NPLs $\quad 22$

2.7.2.5 Lenient Credit Terms 23

2.7.2.6 Credit Orientation 24

$\begin{array}{ll}\text { 2.7.2.7 Bank Size } & 24\end{array}$

2.7.2.8 Cost Efficiency 25

$\begin{array}{ll}\text { 2.7.2.9 Ownership structure } & 25\end{array}$

2.7.2.10 Poor Loan Follow-up (Monitoring) 25 
2.7.3 Macroeconomic factors \&Banking Factors and Non performing loans

2.7.4 Credit risk Management and Non performing loans 31

2.8 Banking System in Sri Lanka 33

2.9 Chapter Summary $\quad 34$

\section{CHAPTER-03 CONCEPTULIZATION AND METHODOLOGY}

3.1 Introduction $\quad 35$

3.2 Description of the Study Area

3.3 Conceptual Framework $\quad 36$

$\begin{array}{ll}3.4 \text { Operationalization } & 37\end{array}$

3.5 The Research Design $\quad 37$

3.6 Data Collection Sources and Methods $\quad 37$

3.7 Sample Size $\quad 38$

3.7.1 Data Analysis Method $\quad 38$

3.8 Sri Lankan banking sector performance during last 6 years 39

3.9 Method of Data Evaluation $\quad 40$

3.10 Research Hypotheses $\quad 40$

3.11 Validity and Reliability $\quad 41$

$\begin{array}{ll}3.11 .1 \text { Validity } & 41\end{array}$

$\begin{array}{ll}3.11 .2 \text { Reliability } & 42\end{array}$

$\begin{array}{ll}3.10 \text { Summary } & 42\end{array}$

\section{CHAPTER-04 DATA PRESENTATION AND ANALYSIS}

4.1 Introduction 43

4.2 presenting Personal Information 43

4.2.1 Gender $\quad 43$

4.2.2 Age 44

$\begin{array}{ll}4.2 .3 \text { Education } & 44\end{array}$

4.2.4 Job category $\quad 45$

$\begin{array}{ll}4.2 .5 \text { Experience } & 45\end{array}$ 
4.2.6 Types of Bank $\quad 46$

4.3 Presenting Dimension of Variables $\quad 47$

4.3.1 Bank Ownership $\quad 47$

4.3.2 High interest rate $\quad 50$

4.3.3 Rapid loan growth $\quad 54$

4.3.4 Credit assessment $\quad 59$

4.3.5 Credit Monitoring $\quad 63$

$\begin{array}{ll}\text { 4.3.6 Collateral Security } & 66\end{array}$

$\begin{array}{ll}\text { 4.3.7 Credit Terms } & 70\end{array}$

$\begin{array}{ll}\text { 4.3.8 Credit Size } & 73\end{array}$

$\begin{array}{ll}\text { 4.3.9 Poor risk assessment } & 78\end{array}$

4.4 Factor Ranking $\quad 83$

$\begin{array}{ll}4.5 \text { Summary } & 83\end{array}$

\section{CHAPTER-05 DISCUSSION, CONCLUSIONS AND RECOMMENDATIONS}

83-88

$\begin{array}{lr}5.1 \text { Introduction } & 84\end{array}$

5.2 Discussion $\quad 84$

$\begin{array}{ll}5.3 \text { Conclusion } & 86\end{array}$

$\begin{array}{ll}5.4 \text { Recommendations } & 87\end{array}$ 


\section{LIST OF TABLES}

Table no. Title

Page No

3.0: Operationalization $\quad 37$

3.1: Description of Sampling 38

3.2: IBSL Report $\quad 40$

3.3: Decision Rule $\quad 40$

4.1: Descriptive Statistics of bank ownership $\quad 47$

4.2: Loan default is related banks ownership type 47

4.3: Private banks loans are high default as compare state banks 48

4.4: Recovery Efficiency depends on Bank Ownership 48

4.5: State Banks mostly lending loans to Government servant 49

4.6: Correlation of Bank ownership and Nonperforming Loan 49

4.7: Descriptive Statistics of high interest rate $\quad 50$

4.8: Loans with big interest rate tend to turn to NPL 51

4.9: Charging big interest rate leads to loan default 51

4.10: Loan price affects loan performance 52

4.11: High Default interest leads to high NPL 53

4.12: Correlation of higher interest rate and Nonperforming Loan 53

4.13: Model summary high interest rates and nonperforming loans 54

4.14: ANOVA high interest rates and nonperforming loans 54

4.15: Coefficients of high interest rates and nonperforming loans 55

4.16: Descriptive statistics of rapid loan growth 55

4.17: Aggressive lending leads to large NPL volume/ratio 56

4.18: Banks whose credit growth is rapid experience huge NPL level 56

4.19: Bank's great risk appetite is cause for NPL 57

4.20: Compromised integrity in lending leads to loan default 57

4.21: Correlation of Rapid Loan Growth and Nonperforming Loan 58

4.22: Model summary of rapid loan growth and non performing loans 58

4.23: ANOVA of rapid loan growth and non performing loans 59

4.24: Coefficients of rapid loan growth and non performing loans 59

4.25: Descriptive statistics of credit assessment $\quad 60$ 
4.26: Know your customer (KYC) policy Of Banks lead to high loan quality $\quad 60$

4.27: Good loan underwriting ensures Loan performance 61

4.28: Easily admitted borrowers usually default $\quad 61$

4.29: Default in some area is ascribed to the culture of the borrowers 62

4.30: Correlation of credit assessment and non performing loan 62

4.31: Descriptive statistics of credit monitoring 63

4.32: Strict monitoring ensures loan performance $\quad 64$

4.33: Poorly assessed and advanced loans may perform well if properly monitored 64

4.34: Loan follow up is directly related to occurrence of nonperforming loans 65

4.35: Banks with higher budget for loan monitoring have lower non performing loans

4.36: Correlation of credit monitoring and non performing loan 66

4.37: Descriptive statistics of collateral security $\quad 67$

4.38: Collateralized loans perform well $\quad 67$

4.39: Collateralizing loans help protect loan default $\quad 68$

4.40: Most of the time non collateralized loans are defaulted 68

4.41: Most of the time collateralized loans are defaulted 68

4.42: Correlation between collateral security and non performing loan 69

4.43: Descriptive statistics of credit terms $\quad 70$

4.44: Lenient / lax credit term cause loan default 71

4.45: Borrowers default because they don't understand credit terms well 71

4.46: Poorly negotiated credit terms lead to loan non performance 71

4.47: High legal aspects represented the credit terms lead to non performing loans 72

4.48: Correlation between credit terms and non performing loan 73

4.49: Descriptive statistics of credit terms $\quad 74$

4.50: Having large number of borrowers causes loan default 74

4.51: Loans default rate is directly related to Credit size 75

4.52: With growth in banks target comes growth on NPL 75

4.53: Most of the Existing borrowers made loan Default 75

4.54: Correlation between credit size and non performing loan 76

4.55: Model summary of credit size and non performing loan 77

4.56: ANOVA of credit size and non performing loan 78

4.57: Coefficients of credit size and non performing loan 78 
4.58: Descriptive statistics of poor risk assessment

4.59: Poor risk assessment would lead to loan default

4.60: Maintain low level NPL Provision

4.61: Low level risk arrangement due to High cost

80

4.62: Maintain In effective Recovery Channels

80

4.63: Correlations of poor risk assessment and non performing loan 81

4.64: Model summary of poor risk assessment and non performing loan

4.65: ANOVA of poor risk assessment and non performing loan

82

4.66: Coefficients of poor risk assessment and non performing loan

82

4.67 Factor ranking

83 


\section{LIST OF FIGURES}

Table no. Title

Page no

3.0: Conceptual frame work 36

4.1: Gender 43

4.2: Age 44

4.3: Education 44

4.4: Job Category 45

4.5: Experience $\quad 45$

4.6: Bank type 46

4.7: bank ownership and Nonperforming loans $\quad 50$

4.8: scatter plot for high interest rates and nonperforming loans 53

4.9: scatter plot for loan growth and nonperforming loans 58

4.10: scatter plot for credit assessment and nonperforming loans 63

4.11: Scatter plot for credit monitoring and nonperforming loans 66

4.12: Scatter plot for collateral security and nonperforming loans 69

4.13: Scatter plot for credit terms and nonperforming loans 73

4.14: Scatter plot for credit size and nonperforming loans 77

4.15: Scatter plot for poor risk assessment and nonperforming loans 81 


\section{CHAPTER 1}

\section{INTRODUCTION}

\subsection{Background}

Banks role in the economy of any country is very significant. They play intermediation function in that they collect money from those who have excess and lend it to others who need it for their investment. Availing credit to borrowers is one means by which banks contribute to the growth of economies.

Lending represents the heart of the banking industry. Loans are the dominant asset and represent 50-75 percent of the total Amount at most banks, generate the largest share of operating income and represent the banks greater risk exposure (Mac Donald and Koch, 2006). Moreover, its contribution to the growth of any country is huge in that they are the main intermediaries between depositors and those in need of fund for their viable projects (creditors) thereby ensure that the money available in economy is always put to good purpose.

Therefore, managing loan in a proper way not only has positive effect on the banks performance but also on the borrower firms and a country as a whole. Failure to manage loans, which make up the largest share of banks assets, would likely lead to the episode of high level of non performing loans.

According to the International Monetary Fund (IMF, 2009), a non- performing loan is any loan in which interest and principal payments are more than 90 days overdue; or more than 90 days' worth of interest has been refinanced on the other hand the Basel Committee1(2001) puts non performing loans as loans left unpaid for a period of 90 days.

\subsection{Problem Statement and Justification}

Financial sector in Sri Lanka is dominated by banking enterprises. In 2013, the banking sector comprised with 33 licensed banks with 12 foreign Licensed Commercial Banks (LCBs) and 21 domestic banks which include 9 licensed specialized banks and 12 local LCBs (CBSL, 2014). The banking sector accounted for about two third of the total assets of the financial system in 2013.Therefore, the strength of the financial system in Sri Lanka to a greater extent dependent on 
the soundness of banking institutions. During recent decades, many countries have witnesses banking crises. These crises have a bad impact on the economy. In addition, banking crises have significant cost. Fonseka (2009) conducted a comparison of NPLs in Bangladesh, Indonesia, Philippines, Malaysia, Thailand and Sri Lanka. Results revealed that Sri Lanka's performance is only better than Bangladesh. As World Bank (2013) explained, Sri Lanka account for moderately high NPL ratio among Asian countries except Bhutan and Pakistan. Low asset quality of Sri Lankan commercial banks is more emphasized when compared that with the developed countries. As to World Bank (2013) Australia, United Kingdom, Canada, New Zealand and Sweden account for less than 2 percent of NPLs in their commercial banking industry. Sri Lanka has experienced a distressed situation in number of commercial banks by recording high NPLs showing the early indicators of problematic bank practices which could have lead to bank failures. According to Central Bank of Sri Lanka (CBSL) by end of year 2013 gross NPL ratio of the country increased to 5.6 percent. The amount of total NPLs of Sri Lankan commercial banking sector is Rs 191 billion.

It's on this basis that this research was conducted to find the bank specific determinants of NPL in Sri Lanka.

\subsection{Objectives}

- To identify the Bank Specific factors which are influencing the Non performing loans in Commercial banks, Sri Lanka.

- To rank the factors based on their importance.

- To analyze the relationship between Bank specific factors and Non performing Loans

\subsection{Research Questions}

- What are bank specific factors influencing the Non performing loans in Commercial banks?

- What are the relationship between Bank specific factors and Non performing Loan? 